\title{
EFFECTS OF REPEATED ADMINISTRATION OF DITHIOL CHELATING AGENT - SODIUM 2,3-DIMERCAPTO-1-PROPANESULPHONATE (DMPS) - ON BIOCHEMICAL AND HAEMATOLOGICAL PARAMETERS IN RABBITS
}

\author{
Vladimír Geršl ${ }^{1}$, Radomír Hrdina ${ }^{2}$, Jaroslava Vávrová ${ }^{3}$, Magdalena Holečková $^{3}$, Vladimír Palička ${ }^{3}$, \\ Jaroslava Voglová, Yvona Mazurová ${ }^{5}$, Jiř̌i Bajgar ${ }^{6}$ \\ ${ }^{1}$ Department of Pharmacology, Charles University, Faculty of Medicine, Hradec Králové; \\ (Head: prof. MUDr. J. Martínková, CSc.) \\ 2 Department of Pharmacology and Toxicology, Charles University, Faculty of Pharmacy, Hradec Králové; \\ (Head: prof. MUDr. Z. Fendrich, CSc.) \\ ${ }^{3}$ Institute of Clinical Biochemistry and Diagnostics, University Teaching Hospital, Hradec Králové; \\ (Head: doc. MUDr. V. Palička, CSc.) \\ ${ }^{4}$ Department of Clinical Hematology, University Teaching Hospital, Hradec Králové; \\ (Head: prof. MUDr. L. Chrobák, CSc.) \\ ${ }^{5}$ Department of Histology, Charles University, Faculty of Medicine, Hradec Králové; \\ (Head: prof. MUDr. S. Němeček, DrSc.) \\ 6 Military Medical Academy, Hradec Králové; \\ (Head: doc. MUDr. S. Býma, CSc.)
}

\begin{abstract}
Summary: The effects of weekly intravenously administered a dithiol chelating agent - sodium 2,3-dimercaptopropanesulphonate (DMPS) - in a single dose of $50 \mathrm{mg} / \mathrm{kg} /$ week for 10 weeks on biochemical and haematological parameters were studied in rabbits. DMPS was well tolerated, an increase in body weight was similar in the DMPS-treated and control animals. DMPS caused significant decrease in plasma calcium and vitamin E concentrations at the end of the experiment. No significant differences in haematological parameters between the DMPS and control groups were observed. A significant decrease in magnesium content in myocardial tissue was observed in the DMPS-treated rabbits. The above-mentioned biochemical changes should be taken into account in studies of possible chelating and radical scavenging effects of DMPS in various pathological conditions.
\end{abstract}

Key words: 2,3-dimercapto-1-propanesulphonate; DMPS; Chelating agents; Dithiols; Biochemistry; Haematology; Myocardial elements; Rabbit

\section{Introduction}

Early in the eighties it was shown that some newer complexing agents, e.g. sodium 2,3-dimercapto-1-propanesulphonate (DMPS; unithiol), or meso-2,3-dimercaptosuccinic acid (DMSA), were effective in mercury, arsenic and lead poisoning. Compared to 2,3-dimercaptopropanol (BAL), the newer agents were of significantly lower toxicity. Moreover, they can be administered orally or intravenously (1). Thus, it can be expected that older chelating agents (e.g. BAL, $\mathrm{CaNa}_{2}$ EDTA) will be replaced by DMPS and DMSA (2). Effectiveness of the first mentioned agent - DMPS - was also demonstrated in various experimental haevy metal intoxications, e.g in As, $\mathrm{Hg}$, Au intoxications $(8,23,15)$.

In addition to haevy metal-chelating activity, DMPS as a dithiol agent may act as an oxygen radical scavenger and thus it may inhibit lipid peroxidation $(4,3)$. Oxidative stress plays an important role in various pathological conditions, e.g. in the anthracycline cardiotoxicity (20). In relation to the study of DMPS in the above-mentioned pathological state, we have studied changes of biochemical and haematological parameters in the course of repeated (10 weeks) intravenous DMPS administration in rabbits. In addition, myocardial content of some elements (calcium, potassium, magnesium, iron, selenium) was also measured at the termination of the experiment.

\section{Methods}

Chemicals

2,3-dimercaptopropane-1-sulfonic acid, sodium salt (Sigma Chemie, Czech Republic); ketamin (Narkamon 5\% inj., Léči- 
va, Czech Republic); pentobarbital (Nembutal Sodium, Abbott, USA); aqua pro injectione (Biotika, Slovakia), saline (Solutio natrii chlorati isotonica, Biotika, Slovakia).

\section{Experimental design}

Medium size Chinchilla male rabbits of average weight $3.0 \mathrm{~kg}$ and age 4 months at the beginning of the experiment were used. This experiment followed the Law of the Czech National Council for the protection of animals against cruelty, as well as the European convention for the protection of vertebrate animals used for experimental and other scientific purposes of the Council of Europe, and was under the supervision of the Ethics Committee of the Medical Faculty, Charles University, Hradec Králové.

DMPS was administered i.v. to twelve rabbits in a dose of $50 \mathrm{mg} / \mathrm{kg}$ once weekly for 10 weeks. DMPS was dissolved in aqua pro injectione immediately before administration in a concentration $50 \mathrm{mg} / \mathrm{ml}$. Fifteen control rabbits were given saline i.v. in corresponding volume $(1.0 \mathrm{ml} / \mathrm{kg})$. The weight of rabbits was monitored during the experiment. Biochemical and haematological parameters were determined in arterial blood samples (plasma, or serum, resp.) before the 1 st and 5 th administration of the drug and at the end of the experiment (3-5 days after the 10th administration of the drug). After the sacrifice of rabbits by i.v. pentobarbital overdosing at the 11th week, the gross autopsy was performed, heart was excised, sample of the left ventricle was removed for determination of elements content calcium, potassium, magnesium, iron and selenium.

\section{Biochemical parameters}

The following biochemical parameters were determined in plasma (serum) samples using automatic analyser Hitachi 717 (Japan): Na, K, Ca, Cl, Mg, phosphate, glucose, urea, creatinine, uric acid, bilirubin, lactate dehydrogenase (LD), alanine aminotransferase (ALT), aspartate aminotransferase (AST), creatine kinase (CK), alkaline phosphatase (ALP), cholesterol, triglycerides, proteins incl. electrophoresis, glutathione peroxidase (GSH-px), glutathione (GSH), malone dialdehyde (MDA), vitamin E.

\section{Haematological parameters}

Parallel to biochemical parameters, the following haematological parameters were determined using analyser Coulter T890 (USA): white blood cells count and white blood picture, red blood cells count, haemoglobin, haematocrit and thrombocytes count.

\section{Myocardial content of elements}

The content of calcium $(\mathrm{Ca})$, potassium $(\mathrm{K})$, magnesium $(\mathrm{Mg})$, iron $(\mathrm{Fe})$ and selenium $(\mathrm{Se})$ was measured in samples of dry, mineralized (using microwave digestion with nitric acid and hydrogen peroxide in microwave oven, Milestone, Italy) left ventricular tissue and expressed in $\mu \mathrm{mol} / \mathrm{g}$ (Se in $\mathrm{nmol} / \mathrm{g}$ ) of dry tissue. $\mathrm{Ca}, \mathrm{Mg}$ and Se were determined by atomic absorption spectrophotometry using an analyser Unicam Sollar 959 (USA). Content of K and Fe was measured photometrically using an apparatus Eppendorf Efox 5053 (Germany), and Hitachi 717 (Japan), resp.

\section{Statistical analysis}

The data are presented as means \pm S.E.M. Significance was estimated with the adequate t-test at the level $p \leq 0.05$ (9).

\section{Results}

\section{Body weight}

The initial values of body weight were $3193 \pm 68 \mathrm{~g}$ in the control group, and $3042 \pm 60 \mathrm{~g}$ in the DMPS group, resp. The weight gain in both groups of rabbits was almost identical during the experiment (Fig. 1).

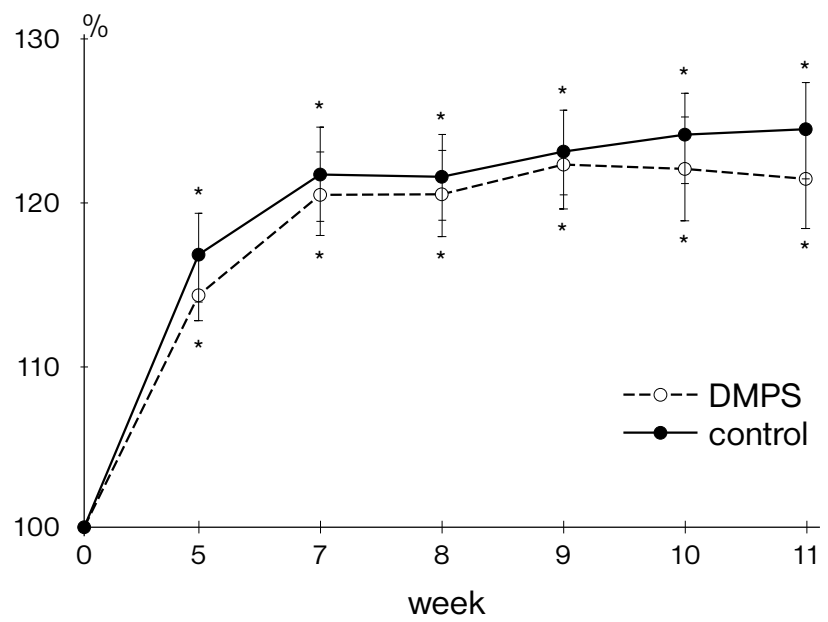

Fig. 1: Body weight gain (\%) in the control and DMPS treated rabbits during the experiment (11 weeks); $p<0,005$ compared to the initial value.

\section{Biochemical parameters}

As shown in tab. 1, there were some significant differences between control and DMPS treated animals at the beginning of the experiment in some measured biochemical parameters. In the DMPS group, there was a higher concentration (or activity) of Na, urea, ALT, albumin, GSH-px and GSH, compared to the control group. No consistent trends were found in the measured parameters during the experiment (i.e., in the 5 th week). At the end of the experiment, a significant decrease in Ca plasma concentration was found in DMPS treated rabbits compared to the control group. In addition, there was a significantly lower increase in CK activity in DMPS group vs. control group. In the middle of the experiment (the 5th week), there was also transient, but significant increase in some globulin fractions $\left(\alpha_{2}, \beta, \gamma\right)$ of plasma proteins in DMPS treated rabbits. Compared to the initial values, there was a significant decrease in vitamin $\mathrm{E}$ concentration at the end of the experiment in the DMPS group. 
Table 1: Biochemical parameters (initial = absolute values) and their changes (\%) during repeated i.v. administration of DMPS (50 mg/kg/week).

\begin{tabular}{|c|c|c|c|}
\hline \multirow[t]{2}{*}{ Parameter } & \multicolumn{3}{|c|}{$\begin{array}{l}\text { Time interval (weeks) } \\
\text { control group }\left(\mathrm{n}_{1}=15\right) \\
\text { DMPS group }\left(\mathrm{n}_{2}=12\right)\end{array}$} \\
\hline & 1 (initial) & 5 & 11 (final) \\
\hline $\begin{array}{l}\text { sodium } \\
(\mathrm{mmol} / \mathrm{l})\end{array}$ & $\begin{array}{l}141.7 \pm 0.7 \\
144.5 \pm 0.7^{\#}\end{array}$ & $\begin{array}{c}101.2 \pm 0.7 \\
99.0 \pm 0.7^{\#}\end{array}$ & $\begin{array}{c}101.9 \pm 0.8^{*} \\
99.8 \pm 1.2\end{array}$ \\
\hline $\begin{array}{l}\text { potassium } \\
(\mathrm{mmol} / \mathrm{l})\end{array}$ & $\begin{array}{l}4.0 \pm 0.2 \\
3.9 \pm 0.1\end{array}$ & $\begin{array}{l}93.6 \pm 3.2 \\
92.4 \pm 4.1\end{array}$ & $\begin{array}{c}83.9 \pm 5.0^{*} \\
106.0 \pm 11.6\end{array}$ \\
\hline $\begin{array}{l}\text { chloride } \\
(\mathrm{mmol} / \mathrm{l})\end{array}$ & $\begin{array}{r}102.2 \pm 1.0 \\
104.3 \pm 0.8\end{array}$ & $\begin{array}{c}102.4 \pm 1.2 \\
97.7 \pm 1.0^{\# *}\end{array}$ & $\begin{array}{l}100.6 \pm 1.5 \\
103.2 \pm 2.7\end{array}$ \\
\hline $\begin{array}{l}\text { calcium } \\
(\mathrm{mmol} / \mathrm{l})\end{array}$ & $\begin{array}{l}3.1 \pm 0.1 \\
3.2 \pm 0.1\end{array}$ & $\begin{array}{l}102.7 \pm 4.6 \\
106.4 \pm 2.2^{*}\end{array}$ & $\begin{array}{l}96.5 \pm 2.2 \\
86.8 \pm 4.1^{\#^{*}}\end{array}$ \\
\hline $\begin{array}{l}\text { magnesium } \\
(\mathrm{mmol} / \mathrm{l})\end{array}$ & $\begin{array}{r}0.94 \pm 0.08 \\
1.02 \pm 0.03\end{array}$ & $\begin{array}{c}359.3 \pm 253.0 \\
96.5 \pm 8.7\end{array}$ & $\begin{array}{c}893.6 \pm 792.8 \\
99.9 \pm 4.0\end{array}$ \\
\hline $\begin{array}{l}\text { phosphate } \\
(\mathrm{mmol} / \mathrm{l})\end{array}$ & $\begin{array}{l}1.90 \pm 0.10 \\
1.85 \pm 0.07\end{array}$ & $\begin{array}{l}83.1 \pm 3.9^{*} \\
85.8 \pm 3.8^{*}\end{array}$ & $\begin{array}{l}77.2 \pm 4.7^{*} \\
75.2 \pm 2.9^{*}\end{array}$ \\
\hline $\begin{array}{l}\text { glucose } \\
(\mathrm{mmol} / \mathrm{l})\end{array}$ & $\begin{array}{r}10.8 \pm 0.8 \\
8.7 \pm 0.9\end{array}$ & $\begin{array}{c}100.3 \pm 9.2 \\
118.8 \pm 13.3\end{array}$ & $\begin{array}{c}133.7 \pm 13.8^{*} \\
131.0 \pm 14.4\end{array}$ \\
\hline $\begin{array}{l}\text { urea } \\
(\mathrm{mmol} / \mathrm{l})\end{array}$ & $\begin{array}{l}7.9 \pm 0.3 \\
9.7 \pm 0.3^{\#}\end{array}$ & $\begin{array}{r}111.7 \pm 6.3 \\
95.4 \pm 4.4\end{array}$ & $\begin{array}{r}101.4 \pm 4.8 \\
92.7 \pm 8.0\end{array}$ \\
\hline $\begin{array}{l}\text { creatinine } \\
(\mu \mathrm{mol} / 1)\end{array}$ & $\begin{array}{l}91.2 \pm 4.1 \\
90.9 \pm 1.9\end{array}$ & $\begin{array}{c}106.9 \pm 2.8^{*} \\
106.9 \pm 3.8\end{array}$ & $\begin{array}{c}108.4 \pm 4.8 \\
109.9 \pm 5.3\end{array}$ \\
\hline $\begin{array}{l}\text { uric acid } \\
(\mu \mathrm{mol} / \mathrm{l})\end{array}$ & $\begin{array}{c}12.5 \pm 1.8 \\
13.9 \pm 2.3\end{array}$ & $\begin{array}{l}72.3 \pm 11.6^{*} \\
83.2 \pm 34.5\end{array}$ & $\begin{array}{r}100.8 \pm 34.4 \\
94.9 \pm 53.3\end{array}$ \\
\hline $\begin{array}{l}\text { bilirubin } \\
(\mu \mathrm{mol} / 1)\end{array}$ & $\begin{array}{l}6.3 \pm 0.3 \\
6.3 \pm 0.2\end{array}$ & $\begin{array}{l}86.1 \pm 3.5^{*} \\
81.0 \pm 2.4^{*}\end{array}$ & $\begin{array}{l}84.0 \pm 3.4^{*} \\
80.2 \pm 2.9^{*}\end{array}$ \\
\hline $\begin{array}{l}\text { LD } \\
(\mu \mathrm{kat} / 1)\end{array}$ & $\begin{array}{l}7.1 \pm 2.0 \\
7.8 \pm 1.0\end{array}$ & $\begin{array}{r}249.1 \pm 80.3 \\
121.8 \pm 26.5\end{array}$ & $\begin{array}{c}300.3 \pm 139.0 \\
108.8 \pm 19.7\end{array}$ \\
\hline $\begin{array}{l}\text { ALT } \\
(\mu \mathrm{kat} / \mathrm{l})\end{array}$ & $\begin{array}{l}1.2 \pm 0.1 \\
1.8 \pm 0.1^{\#}\end{array}$ & $\begin{array}{c}102.1 \pm 6.6 \\
83.9 \pm 3.9^{\# *}\end{array}$ & $\begin{array}{c}92.2 \pm 7.4 \\
75.1 \pm 4.3^{*}\end{array}$ \\
\hline $\begin{array}{l}\text { AST } \\
(\mu \mathrm{kat} / 1)\end{array}$ & $\begin{array}{c}0.49 \pm 0.05 \\
0.58 \pm 0.04\end{array}$ & $\begin{array}{l}146.7 \pm 16.8^{*} \\
104.8 \pm 8.3^{\#}\end{array}$ & $\begin{array}{l}114.0 \pm 9.5 \\
118.2 \pm 15.7\end{array}$ \\
\hline $\begin{array}{l}\text { CK } \\
(\mu \mathrm{kat} / 1)\end{array}$ & $\begin{array}{r}23.6 \pm 4.0 \\
32.4 \pm 3.8\end{array}$ & $\begin{array}{l}134.8 \pm 22.0 \\
105.0 \pm 14.1\end{array}$ & $\begin{array}{c}202.4 \pm 24.9^{*} \\
124.2 \pm 18.1^{\#}\end{array}$ \\
\hline $\begin{array}{l}\text { ALP } \\
(\mu \mathrm{kat} / 1)\end{array}$ & $\begin{array}{l}3.4 \pm 0.3 \\
2.9 \pm 0.2\end{array}$ & $\begin{array}{r}102.1 \pm 11.4 \\
85.9 \pm 6.1^{*}\end{array}$ & $\begin{array}{l}53.9 \pm 6.9^{*} \\
55.7 \pm 5.3^{*}\end{array}$ \\
\hline $\begin{array}{l}\text { cholesterol } \\
(\mathrm{mmol} / \mathrm{l})\end{array}$ & $\begin{array}{r}1.04 \pm 0.11 \\
1.15 \pm 0.09\end{array}$ & $\begin{array}{c}119.9 \pm 11.4 \\
94.2 \pm 5.6\end{array}$ & $\begin{array}{c}79.4 \pm 8.3^{*} \\
214.6 \pm 145.4\end{array}$ \\
\hline $\begin{array}{l}\text { triglycerides } \\
(\mathrm{mmol} / \mathrm{l})\end{array}$ & $\begin{array}{l}1.03 \pm 0.09 \\
0.85 \pm 0.09\end{array}$ & $\begin{array}{c}91.7 \pm 8.0 \\
137.8 \pm 18.4^{\#}\end{array}$ & $\begin{array}{l}133.1 \pm 13.0^{*} \\
168.7 \pm 19.4^{*}\end{array}$ \\
\hline
\end{tabular}

Table 1 (cont'd)

\begin{tabular}{|l|c|c|c|}
\hline protein (g/l) & $\begin{array}{c}62.3 \pm 1.1 \\
64.7 \pm 0.8\end{array}$ & $\begin{array}{c}107.4 \pm 2.7^{*} \\
97.7 \pm 5.8\end{array}$ & $\begin{array}{c}99.7 \pm 2.5 \\
101.3 \pm 3.4\end{array}$ \\
\hline \multicolumn{3}{|c|}{} \\
electrophoresis: \\
\hline \multicolumn{3}{|c|}{} \\
\hline albumin (\%) & $66.3 \pm 1.3$ & $103.1 \pm 1.1^{*}$ & $101.2 \pm 2.6$ \\
& $69.8 \pm 1.3^{\#}$ & $95.1 \pm 2.0^{\#}$ & $98.1 \pm 2.0$ \\
\hline$\alpha_{1}$ globulin & $5.6 \pm 0.6$ & $140.9 \pm 50.8$ & $117.6 \pm 22.5$ \\
& $6.2 \pm 0.2$ & see note & $96.3 \pm 8.6$ \\
\hline$\alpha_{2}$ globulin & $6.7 \pm 0.4$ & $92.3 \pm 5.3$ & $97.6 \pm 7.0$ \\
& $5.2 \pm 0.4^{\#}$ & $138.4 \pm 11.1^{\# *}$ & $122.5 \pm 9.2^{\# *}$ \\
\hline$\beta$ globulin & $11.0 \pm 1.1$ & $109.0 \pm 11.4$ & $87.7 \pm 8.2$ \\
& $9.3 \pm 1.0$ & $184.3 \pm 14.9^{\# *}$ & $95.6 \pm 8.7$ \\
\hline$\gamma$ globulin & $12.5 \pm 0.9$ & $88.9 \pm 7.1$ & $102.7 \pm 8.8$ \\
& $10.6 \pm 0.5$ & $110.6 \pm 6.4^{\#}$ & $111.0 \pm 7.5$ \\
\hline A/G quotient & $2.04 \pm 0.13$ & $114.9 \pm 5.9$ & $103.5 \pm 11.4$ \\
& $2.51 \pm 0.14^{\#}$ & see note & $90.6 \pm 6.1$ \\
\hline GSH-px & $84.0 \pm 7.8$ & $216.9 \pm 22.7^{*}$ & $378.2 \pm 40.4^{*}$ \\
$(\mathrm{U} / \mathrm{g}$ Hb) & $124.2 \pm 9.9^{\#}$ & $223.8 \pm 13.2^{*}$ & $376.4 \pm 26.7^{*}$ \\
\hline GSH & $5.4 \pm 1.2$ & $511.1 \pm 222.3$ & $414.2 \pm 176.1$ \\
$(\mathrm{mg} / \mathrm{g}$ Hb) & $9.6 \pm 1.2^{\#}$ & $181.4 \pm 123.0$ & $240.6 \pm 139.1$ \\
\hline MDA & $0.86 \pm 0.11$ & $92.6 \pm 12.3$ & $116.7 \pm 22.1$ \\
$(\mu \mathrm{mol} / \mathrm{l})$ & $0.87 \pm 0.10$ & $99.2 \pm 10.2$ & $102.0 \pm 10.0$ \\
\hline vitamin E & $4.3 \pm 1.0$ & $74.4 \pm 11.5$ & $97.6 \pm 25.0$ \\
$(\mu \mathrm{mol} / \mathrm{l})$ & $2.6 \pm 0.4$ & $60.0 \pm 20.6$ & $58.9 \pm 15.2^{*}$ \\
\hline
\end{tabular}

LD - lactate dehydrogenase;

ALT - alanine aminotransferase;

AST - aspartate aminotransferase;

CK - creatine kinase;

ALP - alkaline phosphatase;

$\mathrm{A} / \mathrm{G}$ quotient - albumin/globulin quotient;

GSH-px - glutathione peroxidase;

GSH - glutathione;

MDA - malondialdehyde.

Note: values not measured due to interference between fractions of albumin and $\alpha_{1}$ globulin.

Statistical significance $(\mathrm{p} \leq 0.05)$ :

* - compared to the initial value;

\# - between groups

\section{Haematological parameters}

Tab. 2 shows that there were no significant differences in haematological parameters between the DMPS and control groups of rabbits at the beginning of the experiment. Some changes observed during the experiment were comparable in both groups. 
Table 2: Haematological parameters (initial = absolute values) and their changes (\%) during repeated i.v. administration of DMPS (50 mg/kg/week).

\begin{tabular}{|c|c|c|c|}
\hline \multirow[t]{2}{*}{ Parameter } & \multicolumn{3}{|c|}{$\begin{array}{l}\text { Time interval (week) } \\
\text { control group }\left(\mathrm{n}_{1}=15\right) \\
\text { DMPS group }\left(\mathrm{n}_{2}=12\right)\end{array}$} \\
\hline & 1 (initial) & 5 & 11 (final) \\
\hline $\begin{array}{l}\text { leucocytes } \\
\left(10^{9} / 1\right)\end{array}$ & $\begin{array}{l}7.9 \pm 0.7 \\
7.6 \pm 0.6\end{array}$ & $\begin{array}{l}90.1 \pm 7.2 \\
89.9 \pm 6.9\end{array}$ & $\begin{array}{l}57.4 \pm 5.9^{*} \\
61.1 \pm 6.4^{*}\end{array}$ \\
\hline $\begin{array}{l}\text { erythrocytes } \\
\left(10^{12} / 1\right)\end{array}$ & $\begin{array}{l}5.8 \pm 0.2 \\
5.9 \pm 0.1\end{array}$ & $\begin{array}{l}109.4 \pm 2.1^{*} \\
110.3 \pm 2.7^{*}\end{array}$ & $\begin{array}{c}108.8 \pm 2.9^{*} \\
111.7 \pm 1.5^{*}\end{array}$ \\
\hline $\begin{array}{l}\text { haemoglobin } \\
(\mathrm{g} / \mathrm{l})\end{array}$ & $\begin{array}{r}120.9 \pm 3.0 \\
121.3 \pm 2.4\end{array}$ & $\begin{array}{c}113.2 \pm 1.9^{*} \\
115.1 \pm 3.3^{*}\end{array}$ & $\begin{array}{l}110.5 \pm 2.8^{*} \\
117.4 \pm 2.2^{*}\end{array}$ \\
\hline $\begin{array}{l}\text { haematocrit } \\
\text { (ratio) }\end{array}$ & $\begin{array}{l}0.377 \pm 0.081 \\
0.394 \pm 0.008\end{array}$ & $\begin{array}{l}112.1 \pm 2.3^{*} \\
111.7 \pm 2.3^{*}\end{array}$ & $\begin{array}{l}111.1 \pm 3.0^{*} \\
112.6 \pm 2.1^{*}\end{array}$ \\
\hline $\begin{array}{l}\text { MCV } \\
(\mathrm{fl})\end{array}$ & $\begin{array}{l}65.7 \pm 0.5 \\
66.4 \pm 0.5\end{array}$ & $\begin{array}{c}102.6 \pm 1.1^{*} \\
101.2 \pm 1.1\end{array}$ & $\begin{array}{l}102.0 \pm 0.7^{*} \\
100.6 \pm 0.9\end{array}$ \\
\hline $\begin{array}{l}\text { thrombocytes } \\
\left(10^{9} / 1\right)\end{array}$ & $\begin{array}{l}544.3 \pm 34.6 \\
595.3 \pm 42.2\end{array}$ & $\begin{array}{l}84.7 \pm 4.9^{*} \\
75.9 \pm 5.3^{*}\end{array}$ & $\begin{array}{l}83.7 \pm 3.9^{*} \\
78.6 \pm 6.3^{*}\end{array}$ \\
\hline \multicolumn{4}{|c|}{$\underline{\text { differential count }} \quad(\%)$} \\
\hline $\begin{array}{l}\text { band } \\
\text { neutrophils }\end{array}$ & $\begin{array}{c}0.5 \pm 0.2 \\
0.1 \pm 0.1\end{array}$ & $\begin{array}{l}0.0 \pm 0.0 \\
0.0 \pm 0.0\end{array}$ & $\begin{array}{c}0.0 \pm 0.0 \\
12.5 \pm 12.5\end{array}$ \\
\hline $\begin{array}{l}\text { segment } \\
\text { neutrophils }\end{array}$ & $\begin{array}{l}41.5 \pm 3.5 \\
40.3 \pm 4.8\end{array}$ & $\begin{array}{l}97.4 \pm 12.1 \\
98.6 \pm 16.6\end{array}$ & $\begin{array}{r}104.5 \pm 18.2 \\
125.1 \pm 19.5\end{array}$ \\
\hline eosinophils & $\begin{array}{l}2.5 \pm 1.0 \\
1.2 \pm 0.5\end{array}$ & $\begin{array}{c}19.7 \pm 12.1^{*} \\
287.5 \pm 138.1\end{array}$ & $\begin{array}{c}140.7 \pm 45.2 \\
25.0 \pm 17.1^{\# * *}\end{array}$ \\
\hline basophils & $\begin{array}{l}1.7 \pm 0.8 \\
0.6 \pm 0.2\end{array}$ & $\begin{array}{l}75.0 \pm 46.1 \\
10.0 \pm 10.0^{*}\end{array}$ & $\begin{array}{l}72.2 \pm 25.7 \\
66.7 \pm 66.7\end{array}$ \\
\hline monocytes & $\begin{array}{l}2.7 \pm 0.7 \\
2.0 \pm 0.5\end{array}$ & $\begin{array}{l}88.8 \pm 14.2 \\
88.3 \pm 37.5\end{array}$ & $\begin{array}{r}203.6 \pm 56.4 \\
98.3 \pm 46.3\end{array}$ \\
\hline lymphocytes & $\begin{array}{l}48.5 \pm 3.8 \\
55.8 \pm 4.9\end{array}$ & $\begin{array}{c}134.4 \pm 11.8^{*} \\
117.6 \pm 13.5\end{array}$ & $\begin{array}{r}111.2 \pm 13.0 \\
88.2 \pm 10.9\end{array}$ \\
\hline
\end{tabular}

MCV- mean cellular volume.

Statistical significance $(\mathrm{p} \leq 0.05)$ :

* - compared to the initial value;

\# - between groups

\section{Myocardial content of elements}

There was a tendency to a decrease in calcium and potassium content in the myocardium of DMPS treated rabbits. In the case of magnesium, this decrase was significant. The content of iron and selenium were not significantly different in both groups of rabbits (tab. 3).
Table 3: The content of elements - calcium, potassium, magnesium, iron and selenium - in the left cardiac ventricle after repeated i.v. administration of DMPS ( $50 \mathrm{mg} / \mathrm{kg} /$ week $)$.

\begin{tabular}{|l|c|c|c|c|c|}
\hline Group & $\boldsymbol{C a}$ & $\boldsymbol{K}$ & $\boldsymbol{M g}$ & $\boldsymbol{F e}$ & $\boldsymbol{S e}$ \\
\hline $\begin{array}{l}\text { control } \\
\left(\mathrm{n}_{1}=15\right)\end{array}$ & $17.7 \pm 3.1$ & $436.9 \pm 69.7$ & $65.1 \pm 6.8$ & $9.6 \pm 1.8$ & $10.0 \pm 1.2$ \\
\hline $\begin{array}{l}\text { DMPS } \\
\left(\mathrm{n}_{2}=12\right)\end{array}$ & $11.2 \pm 1.3$ & $390.5 \pm 29.5$ & $47.6 \pm 4.6^{\#}$ & $9.5 \pm 1.4$ & $12.7 \pm 1.5$ \\
\hline
\end{tabular}

Means \pm S.E.M. in $\mu \mathrm{mol} / \mathrm{g}$ (Se-nmol/g) of dry tissue.

Statistical significance between groups: \# $\mathrm{p} \leq 0.05$

\section{Discussion}

Repeated i.v. administration of DMPS in a cumulative dose of $0.5 \mathrm{~g} / \mathrm{kg} / 10$ weeks was well tolerated by rabbits. The weight gain of the DMPS treated animals was comparable with that of the control group. After slow i.v. administration of a single dose $50 \mathrm{mg} / \mathrm{kg}$ of DMPS only transient irregularities in respiration were observed. These results correspond to those of other authors who had studied chronic effects of DMPS in other species of experimental animals (19, 22). Rabbits were used in our experiment considering a follow-up study of possible effect of DMPS on anthracycline cardiotoxicity, as the anthracycline model of chronic heart failure in rabbits has been often used for these purposes $(24,5,10)$. Similarly, the selected single dose of DMPS (i.e. $50 \mathrm{mg} / \mathrm{kg}$ ) corresponds on a molar basis to the doses of both experimentally and clinically used cardioprotective agent against anthracycline cardiomyopathy dexrazoxane (ICRF-187) (12).

In some measured biochemical parameters ( $\mathrm{Na}$, urea, ALT, GSH-px, etc.) there were significant differences between the DMPS and control groups at the beginning of the experiment. This fact can be explained by the variation of the biochemical parameters in rabbits (17). A significant decrease in plasma calcium concentration in the DMPS treated rabbits may be possibly due to chelating activity of DMPS. The concentration of other ions, however, was not affected by DMPS treatment. An increase in CK activity in both groups of rabbits during the experiment can be explained by repeated i.m. administration of an anaesthetic agent (ketamine). In the DMPS group this increase was significantly attenuated at the end of the experiment.

The cause of a significant decrease in vitamin E plasma concentration at the end of the experiment in the DMPS treated rabbits (compared to the initial value) may be complex. Rapid oxidation of DMPS after i.v. administration to disulfide forms $(16,18)$ in the blood is supported by kinetic data. Fifteen minutes after i.v. administration of DMPS $(3.0 \mathrm{mg} / \mathrm{kg}$ ) to humans only $12 \%$ of the total DMPS was unchanged, i.e. nearly $90 \%$ of DMPS was oxidized to disulfides (14). In the cells disulfide forms of DMPS can be 
reduced at the expense of vitamin $\mathrm{E}$ or by involving glutathione-disulfide exchange reaction (21). In addition, depletion of cytosol GSH may contribute to the attenuated regeneration of the membrane-bound vitamin $\mathrm{E}(7,13)$.

Doses of DMPS used in this study caused no significant changes in haematological parameters. Higher doses of DMPS can cause anaemia due to copper deprivation, as observed by Szinich et al. (22) in dogs treated i.v. with DMPS $2 \times 75 \mathrm{mg} / \mathrm{kg}$ daily for 10 weeks.

In the DMPS group, there was a significant lower content of $\mathrm{Mg}$ in the myocardium of the left ventricle. There was also tendency to a decrease in $\mathrm{Ca}$ and $\mathrm{K}$ myocardial content, in the case of $\mathrm{Ca}$ the decrease was near the level of statistical significance $(p=0.069)$. On the other hand, the content of Fe and Se was not practically affected by DMPS treatment. The described changes in mineral concentrations, especially those concerned magnesium, calcium and partially iron, were consistent with findings of Bosque, et. al. (1990).

In conclusion, experimental data of our study confirmed low toxicity of repeatedly i.v. administered DMPS in rabbits. In respect to a possible use of this dithiol chelating agent in other pathological states than haevy metal intoxications (e.g. in those where an oxidative stress plays a role), one should take into account distinct effects of DMPS on the myocardial content of some important elements, particularly of magnesium and calcium.

\section{Acknowledgements}

The author wish to thank Mrs. L. Koželuhová for her technical assistance, and Dr. E. Ettlerová for statistical evaluation of the results. This study was supported by means of Internal Grant of the Charles University No. 256/1994, and by IGA MH CR No. 4212-3/97.

\section{References}

1. Aaseth J. Recent advance in the therapy of metal poisonings with chelating agents. Hum Toxicol 1983;2:257-72.

2. Aposhian HV, Maiorino RM, Gonzalez-Ramirez D, Zuniga-Charles M, Xu Z, Hurlbut KM, Junco-Munoz P, Dart RC, Aposhian MM. Mobilization of haevy metals by newer, therapeutically useful chelating agents. Toxicology 1995;97:23-38.

3. Benov LC, Benchev IC, Monovich OH. Thiol antidotes effect on lipid peroxidation in mercury-poisoned rats. Chem Biol Interact 1990;76:321-32.

4. Benov LC, Ribarov SR, Monovich OH. Study of activated oxygen production by some thiols using chemiluminiscence. Gen Physiol Biophys 1992;11:195-202.

5. Bocherens-Gadient SA, Quast U, Nussberger J, Brunner HR, Hof RP. Chronic adriamycin treatment and its effect on the cardiac $\beta$-adrenergic system in the rabbit. J Cardiovasc Pharmacol 1992;19:770-8.

6. Bosque MA, Domingo JL, Paternain JL, Llobet JM, Corbella J. Evaluation of the developmental toxicity of 2,3- dimercapto-1-propanesulphonate (DMPS) in mice. Effect on mineral metabolism. Toxicology 1990;62:311-20

7. Coudray C, Boucher F, Deleiris J, Favier A. Modulation by selenium supplementation of lipid peroxidation induced by chronic administration of adriamycin in rats. Nutrition 1995;11 (Suppl.):512-6.

8. Flora SJ, Dube SN, Arora U, Kannan GM, Shukla MK, Malhotra PR. Therapeutic potential of meso- 2,3-dimercaptosuccinic acid or 2,3-dimercaptopropane-1-sulphonate in chronic arsenic intoxication in rats. Biometals 1995;8: 111-6.

9. Gad SC, Weil Cs. Statistics for toxicologists. In: Hayes AW (ed). Principles and methods of toxicology. 2nd ed., New York:Raven Press, 1989;445-6.

10. Geršl V, Mazurová Y, Bajgar J, Mělka M, Hrdina R, Palička V. Lack of cardiotoxicity of a new antineoplastic agent, a synthetic derivative of indenoisochinoline: comparison with daunorubicin in rabbits. Arch Toxicol 1996;70:645-51

11. Geršl V, Hrdina R. Noninvasive polygraphic cardiac changes in daunorubicin-induced cardiomyopathy in rabbits. Sb Ved Pr Lek Fak Univerzity Karlovy Hradec Králové 1994;37:49-55.

12. Green MD, Alderton P, Gross J, Muggia FM, Speyer JL. Evidence of the selective alteration of anthracycline activity due to modulation by ICRF-187 (ADR-529). Pharmac Ther 1990;48:61-9.

13. Haenen GRMM. Thiols in oxidative stress. Some implications for catecholamine toxicity. Amsterdam:Free University,1990.182 pp.

14. Hurlbut KM, Maiorino RM, Mayersohn M, Dart RC, Bruce DC, Aposhian HV. Determination and metabolism of dithiol chelating agents. XVI. Pharmacokinetics of 2,3dimercapto-1-propanesulphonate after intravenous administration to human volunteers. J Pharmacol Exp Ther 1994;268:662-8.

15. Inns RH, Rice P. Efficacy of dimercapto chelating agents for the treatment of poisoning by percutaneously applied dichloro(2-chlorovinyl)arsine in rabbits. Hum Exp Toxicol 1993; 12:241-6.

16. Klimmek R, Krettek C, Werner HW. Acute effects of the haevy metal antidotes DMPS and DMSA on circulation, respiration, and blood homeostasis in dogs. Arch Toxicol 1993;67:428-34.

17. Kraus AL, Weisbroth SH, Flatt RE, Brewer N. Biology and diseases of rabbits. In: Fox JG, Cohen BJ, Loew FM, eds. Laboratory animal medicine. Orlando:Academic Press,1984:212-3.

18. Maiorino RM, Weber GL, Aposhian HV. Determination and metabolism of dithiol chelating agents. III. Formation of oxidized metabolites of 2,3-dimercaptopropane-1-sulfonic acid in rabbits. Drug Metab Dispos 1988;16:455-63.

19. Planas-Bohne F, Gabard B, Schaffer EH. Toxicological studies on sodium 2,3-dimercaptopropane-1-sulphonate in the rat. Arzneimittel-Forsch 1980;30:1291-4. 
20. Seifert CF, Thompson DF, Nesser ME. Dexrazoxane in the prevention of doxorubicin-induced cardiotoxicity. Ann Pharmacother 1994;28:1063-72.

21. Stewart JR, Diamond GL. In vivo renal tubular secretion and metabolism of the disulfide of 2,3-dimercaptopropane-1-sulphonate. Drug Metab Dispos 1988;16:189-95.

22. Szinicz L, Wiedemann P, Häring H, Weger N. Effects of repeated treatment with sodium 2,3-dimercaptopropane1-sulphonate in Beagle dogs. Arzneimittel-Forsch 1983;33: 818-21.

23. Takahashi Y, Funakoshi T, Shimada H, Kojima S. The utility of chelating agents as antidotes for nephrotoxicity of gold sodium thiomalate in adjuvant-arthritic rats. Toxicology 1995;97:151-7.
24. Van Vleet JF, Ferrans VJ. Evaluation of vitamin E and selenium protection against chronic adriamycin toxicity in rabbits. Cancer Treat Rep 1980;64:315-7.

Submitted April 1997.

Accepted May 1997.

Doc. MUDr. Vladimír Geršl, CSc., Department of Pharmacology, Charles University, Faculty of Medicine, Šimkova 870, 50001 Hradec Králové, Czech Republic. 